\title{
HUBUNGAN ANTARA KEPRIBADIANDENGAN KEJADIAN RELAPS PADA PASIEN KANKER PAYUDARA DI POLI ONKOLOGI RSUD DR. SOETOMO SURABAYA
}

\author{
Danang Nur Adiwibawa \\ Fakultas Kedokteran Universitas Islam Al-Azhar \\ Jl. Unizar No.20 Turida Mataram \\ email :adiwibawa.dr@gmail.com
}

\begin{abstract}
Background.Breast cancer is a major health problem that affects the lives of millions of women. Some patients have treatment but still found relapse.Suggest personality factors influence relapse breast cancer.But until now it is still controversy. Methods. Analytic research observational case control study to find relationship between personality with the incidence of relapse in breast cancer patients and comparing personality relapse and non relapse. Research in Poli Onkologi RSUD Dr.Soetomo with 56 patients, 28 patients relapse and 28 non relapse.Use Instrument OCEAN-Big Five Inventory 44 Quessioner and Demogarfi Quessioner. Result. There is no relationship between personality with incidence of relapse $(p>0,05)$. neuroticism personality $(29 \%)$ in relapse,extraversion personality (36\%) in non relapse. Conclusion. The incidence of relapse breast cancer is not simply due to personality but maybe other factors.
\end{abstract}

Keyword : Breast cancer, relapse, personality.

\section{PENDAHULUAN}

Insiden kanker payudara di Amerika Serikat pada tahun 2014 sekitar 232.670 kejadian atau sekitar 29\%, dengan tingkat mortalitas sekitar 40.000 kasus atau sekitar 15\% (Siegel et al., 2012). Bila kanker payudara didiagnosis pada stadium awal maka hanya ditemukan kerusakan terbatas pada organ payudara saja.Namun bila diagnosisnya terlambat maka makin berat stadiumnya karena kanker payudara mengalami metastase dan dapat resistensi terhadap pengobatan. Bila telah metastase ke organ lain, maka sangat terbatas terapi yang bisa dilakukan dan mudah terjadi relaps. Metastase kanker payudara bisa ke paru-paru, tulang, otak dan hati, dimana pada fase ini tindakan operasi dikombinasikan dengan radioterapi (Ahmad et al., 2012). Banyak faktor yang menyebabkan terjadinya relaps, antara lain : transformasi sel kanker, umur, lokasi tumor, perjalanan penyakit, genetik, stadium, kemoterapi, radiasi atau terapi hormonal (Meng et al., 2012).

Kepribadian merupakan kombinasi kompleks dari pikiran (cognition), perasaan (affect), dan perilaku (behavior), merupakan keseluruhan cara yang khas, bagaimana seseorang terbentuk dan beradaptasi terhadap perubahan yang terjadi secara berkelanjutan dalam lingkungannya, baik secara internal maupun eksternal. Kepribadian terbentuk melalui proses dari bakat alami, pola pengasuhan dan pengalaman diri (Pervin.,2003; Mc 
Craeet al., 2008; Cloningeret al., 2009).

Dikatakan dalam sebuah studi bahwa hubungan antara kepribadian dan kondisi relaps tidak konsisten. Dikatakan bahwa skor tertinggi adalah extraversion sedangkan skor terendah adalah neurotisicm (Morris, 1981).

Domain kepribadian akan menampakkan lima faktor yang jelas, bila diukur menggunakan banyak skala, dengan lingkup pengukuran yang luas. Kelima faktor tersebut adalah openness $(\mathrm{O})$, conscientiousness (C), extraversion(E), agreeableness (A), neuroticism $(\mathrm{N})$. Kelima domain ini tidak hanya nampak pada penilaian evaluasi oleh profesional, namun dapat dilaporkan secara mandiri (self report) (Mc Craeet al.,2008)., 1984). Kepribadian merupakan hipotesis yang panjang dalam hal penyebab pertumbuhan sel kanker. A.D., Galen (1975) menyatakan perempuan melankolis lebih sering terpapar kanker daripada perempuan yang sanguine. Pada tahun 1962, Kissen dan Eysenck dalam studinya menyatakan hubungan kepribadian dan kanker dimana dilaporkan bahwa pasien kanker menjadi extrovert dan sedikit sekali yang menjadi neurotik bila dibandingkan dengan pasien kanker yang kontrol ke rumah sakit (Greer et al., 1975).

Peran kepribadian dalam munculnya kondisi relaps masih menjadi kontroversi. Seperti penelitian sebelumnya yang dilakukan di Jepang oleh Naoki Nakaya (2003) menyatakan bahwa tidak ada hubungan antara kepribadian dengan munculnya kondisi relaps pada kanker payudara, hubungan antara kepribadian dan kondisi relaps mungkin menjadi akibat namun bukan penyebab kondisi tersebut (Nakaya., 2003). Begitu juga penelitian yang dilakukan di Jepang oleh beberapa peneliti dalam The Miyagi Cohort Study (2015) menyatakan bahwa kepribadian tidak berdampak signifikan terhadap perkembangan dan progresivitas kejadian relaps kanker payudara (Yuko Minami et al.,2015).

Melihat kontroversi beberapa penelitian maka kami ingin membuktikan lebih lanjut hubungan kepribadian dengan kondisi relaps pada pasien kanker payudara. Pada studi pendahuluan yang kami lakukan didapatkan jumlah pasien kanker payudara tidak relaps sekitar $10 \%$ dari jumlah pasien kanker payudara yang kontrol di Poli Onkologi RSUD Dr. Soetomo Surabaya. Dalam satu bulan didapatkan sekitar 30 pasien kanker payudara yang kontrol di Poli Onkologi RSUD Dr. Soetomo Surabaya. Angka relaps tertinggi pada kanker payudara adalah dua tahun setelah pengobatan awal, namun saat itu ukuran kanker sudah besar, sehingga kami sebagai 
Peneliti menetapkan waktu satu tahun setelah pengobatan awal dengan tujuan merupakan waktu yang ideal untuk terjadinya relaps dimana ukuran kanker masih kecil.

\section{METODE PENELITIAN}

Penelitian ini adalah suatu studi analitik observasional dengan bentuk case control study untuk mencari hubungan antara kondisi relaps dengan kepribadian pada pasien kanker payudara yang telah menjalani operasi pada tahun 2014 dan membandingkan kepribadian pasien kanker payudara relaps dengan yang tidak relaps di RSUD Dr. Soetomo Surabaya.

Penelitian ini dilakukan di Instalasi Rawat Jalan Poli Onkologi RSUD Dr. Soetomo Surabaya. Dilaksanakan pada bulan Agustus November 2015. Data yang digunakan dalam penelitian ini difokuskan pada rekam medik pasien kanker payudara yang menjalani operasi pada tahun 2014, dimana setelah 1 tahun kemudian diikuti perkembangannya apakah mengalami relaps maupun tidak relaps.

Populasi penelitian adalah pasien yang didiagnosis sebagai kanker payudara yang telah menjalani operasi pada bulan Januari - Juli pada tahun 2014. Target Populasi adalah pasien kanker payudara yang dioperasi pada bulan Januari - Juli tahun 2014 dan saat ini masih kontrol di Poli Onkologi RSUD Dr. Soetomo. Sampel Populasi adalah pasien kanker payudara yang sesuai kriteria inklusi dan eksklusi serta jumlahnya sesuai perhitungan sampel size. Pengambilan sampel dilakukan secara matching usia antara 40 - 55 tahun. Sampel diambil masing - masing kelompok kasus dan kelompok kontrol. Subyek penelitian sebagai berikut :

- Kasus adalah pasien kanker payudara yang kontrol dan relaps minimal dalam waktu satu tahun, yang telah menjalani operasi baik yang kemoterapi maupun yang tidak.

- Kontrol adalah pasien kanker payudara yang kontrol dan tidak relaps dalam satu tahun.

Setiap subyek penelitian juga dilakukan wawancara dan diberikan kuesioner Big Five Inventory yang pengisiannya membutuhkan waktu sekitar 45 menit. Subyek penelitian akan menerima umpan balik setidaknya setelah dua minggu. Setelah rangkaian penelitian selesai, keikutsertaan subyek pada penelitian dihentikan.

Kriteria Inklusi Kanker Payudara Relaps, yaitu:

1. Pasien kanker payudara (C50.9) yang telah didiagnosa Sejawat Bedah Onkologi termasuk jenis kanker payudara dan telah 
menjalani operasi minimal dalam satu tahun terakhir (2014).

2. Mengalami relaps minimal satu tahun setelah menjalani operasi.

3. Pendidikan minimal lulus Sekolah Menengah Pertama (SMP).

4. Dapat membaca dan menulis dalam bahasa Indonesia.

5. Bersedia mengikuti penelitian.

Kriteria Inklusi Kanker Payudara

Tidak Relaps (kontrol), yaitu:

1. Pasien kanker payudara yang telah didiagnosa Sejawat Bedah Onkologi termasuk jenis kanker payudara dan telah menjalani operasi minimal dalam satu tahun terakhir (2014).

2. Tidak mengalami relaps minimal satu tahun setelah menjalani operasi.

3. Pendidikan minimal lulus Sekolah Menengah Pertama (SMP).

4. Dapat membaca dan menulis dalam bahasa Indonesia.

5. Bersedia mengikuti penelitian.

Kriteria Eksklusi pada penelitian ini adalah gangguan komunikasi sehingga tidak bisa melakukan komunikasi dengan pemeriksa (Psikotik) dan lain-lain.

Metode pengumpulan data yang dilakukan yaitu dengan mengumpulkan data sekunder yang diperoleh dari status rekam medis di Poli Onkologi RSUD Dr Soetomo pada pasien yang menjalani operasi pada tahun 2014, kemudian dipisahkan antara rekam medik pasien kanker payudara relaps dengan rekam medik pasien kanker payudara tidak relaps. Setelah operasi Sejawat Bedah Onkologi akan menulis pada rekam medik bila pasien tersebut mengalami relaps saat kontrol ke Poli Onkologi. Dasar itulah yang kita gunakan untuk memisahkan antara pasien relaps dengan pasien tidak relaps. Sehingga pemisahan relaps dan tidak relaps dilakukan pada satu tahun setelah operasi. Pasien akan diwawancara saat kontrol ke Poli Onkologi RSUD Dr Soetomo atau bila pasien tidak datang akan dihubungi lewat telpon dan akan di home visit.

\section{HASIL DAN PEMBAHASAN}

\section{Hasil Penelitian}

Telah dilakukan penelitian tentang hubungan antara kepribadian dengan kejadian relaps pada pasien kanker payudara yang kontrol di Poli Onkologi RSUD Dr. Soetomo Surabaya. Waktu pelaksanaan pengambilan data subyek penelitian dilakukan pada bulan Agustus sampai bulan November 2015.Alokasi waktu yang digunakan selama pengambilan sampel sesuai dengan jadwal penelitian.

Subyek penelitian diambil dari data rekam medik pasien kanker payudara yang menjalani operasi pada 
tahun 2014, dimana setelah satu tahun kemudian diikuti perkembangannya apakah mengalami relaps atau nonrelaps. Kami menggunakan casecontrol study, dimana terdiri dari 28 pasien relaps dan 28 pasien nonrelaps yang memenuhi kriteria inklusi dan eksklusi. Pengambilan sampel dilakukan secara matching usia antara 40 - 55 tahun.

Tabel 1. Profil karakteristik

\begin{tabular}{|c|c|c|c|}
\hline & Relaps & $\begin{array}{l}\text { Non } \\
\text { Relaps }\end{array}$ & $\begin{array}{l}\text { Nilai } \\
\mathrm{p}\end{array}$ \\
\hline Umur: & & & 1,000 \\
\hline 40 - 49 tahun & $\begin{array}{l}14 \\
(50,0)\end{array}$ & $\begin{array}{l}15 \\
(53,6)\end{array}$ & \\
\hline 50 - 55 tahun & $\begin{array}{l}14 \\
(50,0)\end{array}$ & $\begin{array}{l}13 \\
(46,4) \\
\end{array}$ & \\
\hline Pendidikan: & & & $\mathbf{0 , 4 8 2}$ \\
\hline SMP & $\begin{array}{l}16 \\
(57,1)\end{array}$ & $\begin{array}{l}12 \\
(42,9)\end{array}$ & \\
\hline SMA & $\begin{array}{l}8 \\
(28,6)\end{array}$ & $\begin{array}{l}9 \\
(32,1)\end{array}$ & \\
\hline PT & $\begin{array}{l}4 \\
(14,3)\end{array}$ & $\begin{array}{l}7 \\
(25,0)\end{array}$ & \\
\hline Pekerjaan: & & & 0,561 \\
\hline Bekerja & $\begin{array}{l}7 \\
(25,0)\end{array}$ & $\begin{array}{l}10 \\
(35,7)\end{array}$ & \\
\hline $\begin{array}{l}\text { Tidak } \\
\text { bekerja }\end{array}$ & $\begin{array}{l}21 \\
(75,0)\end{array}$ & $\begin{array}{l}18 \\
(64,3)\end{array}$ & \\
\hline $\begin{array}{l}\text { Status } \\
\text { Pernikahan: }\end{array}$ & & & 1,000 \\
\hline Menikah & $\begin{array}{l}26 \\
(92,9)\end{array}$ & $\begin{array}{l}27 \\
(96,4)\end{array}$ & \\
\hline Bercerai & $\begin{array}{l}2 \\
(7,1) \\
\end{array}$ & $\begin{array}{l}1 \\
(3,6)\end{array}$ & \\
\hline $\begin{array}{l}\text { Penghasilan/ } \\
\text { bulan: }\end{array}$ & & & 0,546 \\
\hline$<2.500 .000$ & $\begin{array}{l}22 \\
(78,6)\end{array}$ & $\begin{array}{l}19 \\
(67,9)\end{array}$ & \\
\hline$\geq 2.500 .000$ & $\begin{array}{l}6 \\
(21,4)\end{array}$ & $\begin{array}{l}9 \\
(32,1)\end{array}$ & \\
\hline $\begin{array}{l}\text { Keluarga } \\
\text { yang }\end{array}$ & & & 1,000 \\
\hline
\end{tabular}

\begin{tabular}{llll}
\hline dibiayai: & & & \\
$\leq 2$ & 19 & 20 & \\
& $(67,9)$ & $(71,4)$ & \\
$>2$ & 9 & 8 & \\
& $(32,1)$ & $(28,6)$ & \\
\hline $\begin{array}{l}\text { Komplikasi } \\
\text { Fisik: }\end{array}$ & & & $\mathbf{0 , 0 0 3}$ \\
Ya & 20 & 8 & \\
& $(71,4)$ & $(28,6)$ & \\
Tidak & 8 & 20 & \\
& $(28,6)$ & $(71,4)$ & \\
& & & \\
\hline Bantuan & & & $\mathbf{0 , 4 2 1}$ \\
Keluarga: & & & \\
Ada & 15 & 11 & \\
& $(53,6)$ & $(39,3)$ & \\
Tidak ada & 13 & 17 & \\
& $(46,4)$ & $(60,7)$ & \\
\hline
\end{tabular}

Responden sebanyak 56 pasien. Responden dibagi dalam dua kelompok, yaitu kelompok umur 40 - 49 tahun sebanyak 14 pasien relaps $(50,0 \%)$ dan 15 pasien nonrelaps (53,6 \%) sedangkan kelompok umur 50 - 55 sebanyak 14 pasien relaps $(50,0 \%)$ dan 13 pasien nonrelaps $(46,4 \%)$.

Responden terbanyak tingkat pendidikan SMP sejumlah 16 pasien relaps $(57,1 \%)$ dan 12 pasien nonrelaps $(42,9 \%)$, kemudian SMA sejumlah 8 pasien relaps $(28,6 \%)$ dan 9 pasien nonrelaps $(32,1 \%)$ dan Perguruan Tinggi sejumlah 4 pasienrelaps $(14,3 \%)$ dan 7 pasien non relaps $(25,0 \%)$.

Responden terbanyak tidak bekerja sebanyak 21 pasien relaps $(75,0$ $\%)$ dan 18 pasien nonrelaps $(64,3 \%)$ sedangkan yang bekerja sebanyak 7 pasien relaps $(25,0 \%)$ dan 10 pasien nonrelaps $(35,7 \%)$. 
Responden terbanyak telah menikah sebanyak 26 pasien relaps (92,9 \%) dan 27 pasien nonrelaps $(96,4$ $\%$ ) sedangkan yang bercerai 2 pasien relaps $(7,1 \%)$ dan 1 pasien nonrelaps (3,6\%).

Responden terbanyak yang penghasilannya $<2.500 .000$ sebanyak 22 pasien relaps(78,6\%) dan 19 pasien nonrelaps $(67,9 \%)$ sedangkan yang penghasilan diatas $\geq 2.500 .000$ sebanyak 6 pasien relaps $(21,4 \%)$ dan 9 pasien nonrelaps $(32,1 \%)$.

Responden terbanyak yang mempunyai tanggungan keluarga $\leq 2$ sebanyak 19 pasien relaps $(67,9 \%)$ dan 20 pasien nonrelaps $(71,4 \%)$ sedangkan yang tanggungan keluarga $>2$ sebanyak 9 pasien relaps $(32,1 \%)$ dan 8 pasien nonrelaps $(28,6 \%)$.

Responden terbanyak yang ada komplikasi fisik sebanyak 20 pasien relaps $(71,4 \%)$ dan 8 pasien nonrelaps $(28,6 \%)$ sedangkan yang tidak ada komplikasi fisik sebanyak 8 pasien relaps $(28,6 \%)$ dan 20 pasien nonrelaps $(71,4 \%)$.

Responden terbanyak adalah keluarga yang tidak mendapat bantuan sebanyak 13 pasienrelaps (46,4\%) dan 17 pasien nonrelaps $(60,7 \%)$ sedangkan yang mendapat bantuan keluarga sebanyak 15 pasien relaps $(53,6 \%)$ dan 11 pasien nonrelaps $(39,3 \%)$.
Semua data variabel pada tabel 1 menunjukkan harga $(p>0,05)$, hanya variabel komplikasi fisik yang menunjukkan harga $(\mathrm{p}<0,05)$, artinya menunjukkan adanya hubungan antara kejadian komplikasi fisik terhadap terjadinya relaps pada pasien kanker payudara, dimana komplikasi fisik pada pasien relaps $(71,4 \%)$ lebih tinggi dari pasien nonrelaps $(28,6 \%)$.

\section{Tabel 2. Gambaran Kepribadian}

OCEAN pada pasien kanker payudara relaps dan

nonrelaps

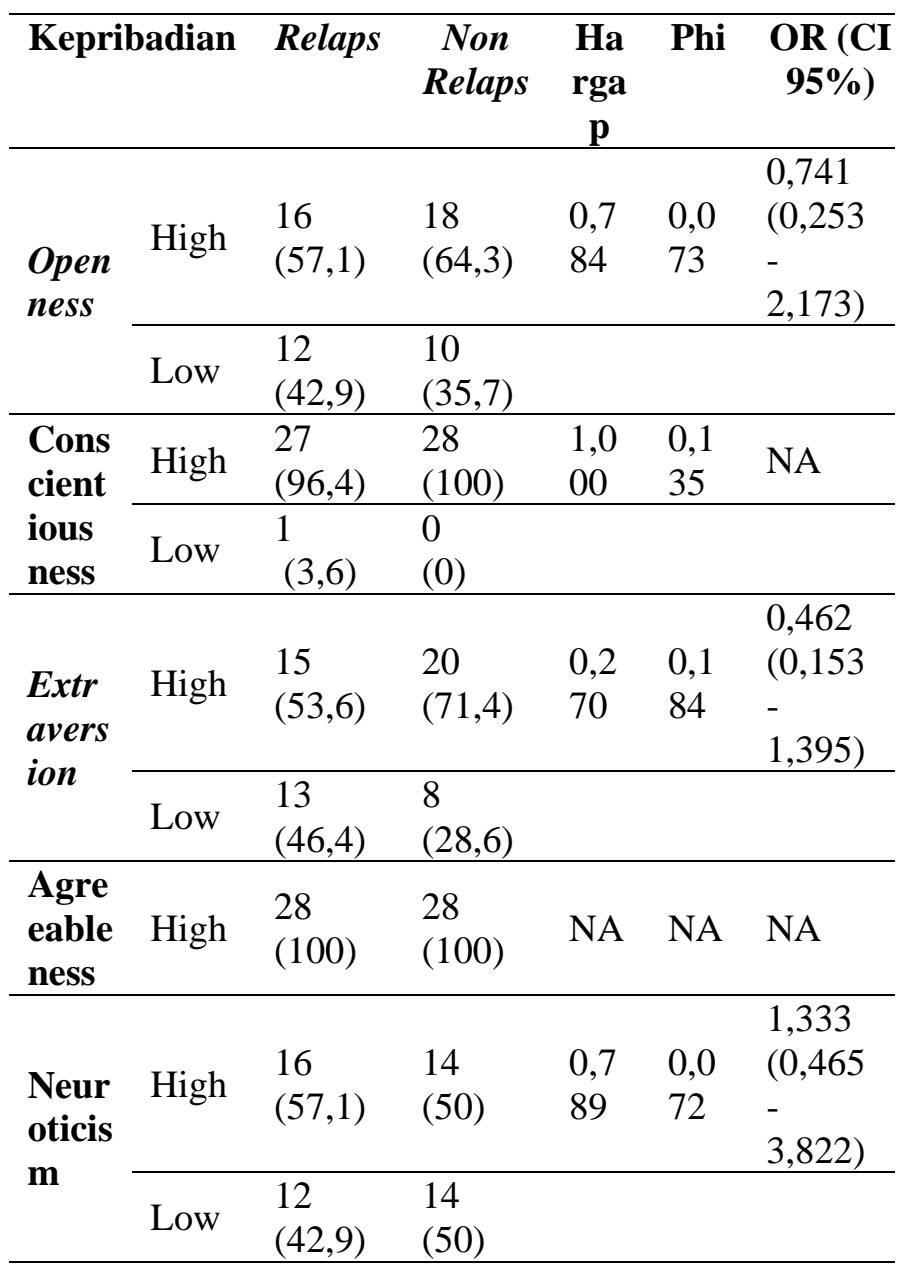

$\mathrm{NA}=$ Not Available 
Pada kepribadian Openness yang memiliki nilai high lebih tinggi pada nonrelaps $(64,3 \%)$ daripada relaps $(57,1 \%)$ sedangkan yang memiliki nilai low lebih tinggi pada relaps $(42,9 \%)$ daripada nonrelaps $(35,7 \%)$. Karena $\mathrm{p}>$ $0,05 \quad(\mathrm{p}=0,784)$ maka tidak ada hubungan antara Kepribadian Openness dengan kejadian relaps pada pasien kanker payudara.

Pada

kepribadian

Conscientiousness yang memiliki nilai high lebih tinggi pada nonrelaps $(100,0 \%)$ daripada relaps $(96,4 \%)$ sedangkan yang memiliki nilai low lebih tinggi pada relaps $(3,6 \%)$ daripada nonrelaps $(0,0 \%)$. Karena $\mathrm{p}>0,05$ $(\mathrm{p}=1,000)$ maka tidak ada hubungan antara Kepribadian Conscientiousness dengan kejadian relaps pada pasien kanker payudara.

Pada kepribadian Extraversion yang memiliki nilai high lebih tinggi pada nonrelaps $(71,4 \%)$ daripada relaps $(53,6 \%)$ sedangkan yang memiliki nilai low lebih tinggi pada relaps $(46,4 \%)$ daripada nonrelaps $(28,6 \%)$. Karena $\mathrm{p}>$ $0,05 \quad(\mathrm{p}=0,270)$ maka tidak ada hubungan antara Kepribadian Extraversion dengan kejadian relaps pada pasien kanker payudara.

Pada kepribadian Agreeableness semua responden memilih nilai high yang tinggi sehingga baik pasien relaps maupun nonrelaps menunjukkan hasil yang sama $(100,0 \%)$. Karena semua responden memilih nilai high dan tidak ada yang memilih nilai low sehingga tidak didapatkan nilai $\mathrm{p}$, maka tidak dapat diketahui apakah ada hubungan antara Kepribadian Agreeableness dengan kejadian relaps pada pasien kanker payudara.

Pada kepribadian Neuroticism yang memiliki nilai high lebih tinggi pada relaps $(57,1 \%)$ daripada nonrelaps $(50,0 \%)$ sedangkan yang memiliki nilai low lebih tinggi pada nonrelaps $(50,0 \%)$ daripada relaps $(42,9 \%)$. Karena $\mathrm{p}>$ $0,05 \quad(\mathrm{p}=0,789)$ maka tidak ada hubungan antara Kepribadian Neuroticism dengan kejadian relaps pada pasien kanker payudara.

\section{Pembahasan}

Perbedaan Kepribadian Antara Pasien Kanker Payudara Relaps dengan NonRelaps Yang Kontrol Di Poli Onkologi RSUD Dr. Soetomo Surabaya

Penilaian kepribadian dengan metode OCEAN pada pasien kanker payudara menggunakan kuesioner Big Five Inventory 44 (BFI 44) yang merupakan perangkat pelaporan mandiri (self report) yang dikembangkan oleh John, Donahue, \& Kentle pada 1991, berisi 44 pertanyaan untuk mengukur kepribadian berdasarkan lima dimensi yaitu extroversion, agreeableness, 
conscentiousness,

neuroticism,

openness. Skala BFI telah diterjemahkan dalam 28 bahasa dan diuji reliabilitas serta validitasnya di 56 negara termasuk Indonesia, secara lintas budaya.Secara umum perangkat ini reliabel, dan validitasnya serupa dengan NEO-PIR. Perangkat BFI dalam bahasa Indonesia telah diuji reliabilitas dan validitasnya oleh Widiarso di Yogyakarta.

Dari 56 subyek penelitian, yang terdiri dari 28 subyek sebagai kasus dan 28 subyek sebagai kontrol menunjukkan adanya perbedaan dimensi kepribadian antara pasien relaps dan pasien nonrelaps (meskipun secara statistik tidak ada beda bermakna). Pasien kanker payudara kelompok relaps memiliki dimensi kepribadian Neuroticism yang lebih tinggi sebesar 7,1 \% dibanding kelompok nonrelaps. Ini berarti pada satu tahun perawatan kanker payudara, kepribadian pasien payudara kelompok relaps bersifat sensitif. Dimana Neuroticism berarti menunjukkan sifat emosional, cemas, pikiran negatif, tidak stabil, temperamen, neurotik dan penakut. Ini semua kemungkinan disebabkan karena pasien yang relaps masih dalam fase denial atau anger terhadap penyakitnya.

Sedangkan pada pasien kelompok nonrelaps memiliki dimensi kepribadian Openness dan Extraversion yang lebih tinggi sebesar 7,2\% dan 17,8\%dibanding kelompok relaps. Ini berarti dalam satu tahun perawatan kanker payudara, kepribadian pasien kanker payudara kelompoknonrelaps bersifat terbuka dan extrovert. Dimana openness menunjukkan sifat imajinatif, cerdas, bijaksana, artistik, terbuka, orisinil, banyak ide. Dan extrovert menunjukkan sifat ekspresif, mudah akrab, ramah, pikiran positif, dominan, apa adanya, tegas. Ini semua disebabkan pasien telah mengalami fase acceptance terhadap sakitnya, memiliki koping yang mature dan dapat memotivasi sesama pasien agar dapat melewati penyakit kanker payudara dengan optimis dan terus berusaha untuk kontrol teratur (Shiota et al., 2006).

Seringkali kita temui komunitas kanker payudara dimana beberapa penderita memberi motivasi bagi penderita yang lain karena merasa senasib sepenanggungan.Ini merupakan wujud dari dimensi extraversion dan openness yang merupakan mekanisme kompensasi dari pasien kanker payudara untuk mengalihkan kondisi sakitnya (Schapiro IR et al, 2001).

Hubungan Antara Kepribadian Dengan Kejadian Relaps Pada Pasien Kanker Payudara Yang Kontrol Di Poli Onkologi RSUD Dr. Soetomo Surabaya

Dari 56 subyek penelitian, yang terdiri dari 28 subyek sebagai kasus dan 
28 subyek sebagai kontrol menunjukkan tidak adanya pengaruh $(\mathrm{p}>0,05)$ antara kepribadian dengan kejadian relaps pada pasien kanker payudara. Hal ini dimungkinkan karena hubungan antara kepribadian dengan kondisi relaps merupakan akibat dan bukan penyebab kondisi tersebut. Seperti penelitian sebelumnya yang dilakukan di Jepang oleh Naoki Nakaya (2003) menyatakan bahwa tidak ada hubungan antara kepribadian dengan munculnya kondisi relaps pada kanker payudara.

Pada kuesioner demografi hanya variabel komplikasi fisik yang memiliki hubungan bermakna terhadap kejadian relaps pada pasien kanker payudara. Ini dimungkinkan karena pada pasienkelompok relaps akan memunculkan berbagai macam komplikasi, seperti bengkak pada lengan, nyeri yang menjalar, gangguan pergerakan pada bahu dan pusing (Farquhar C et al., 2009)

\section{KESIMPULAN}

1. Dalam penelitian ini didapatkan hasil tidak adanya pengaruh antara kepribadian terhadap kejadian relaps, hal ini dipengaruhi oleh dimensi Neuroticism yang sudah dimiliki oleh subyek penelitian sebelum dilakukan penelitian.

2. Penelitian ini menunjukkan perbedaan kepribadian kelompok relaps dan kelompok non relaps, dimana pada kelompok relapsdimensi kepribadiannya Neurotisicm sedangkan kelompok non relaps dimensi kepribadiannya Openness dan Extraversion.

\section{SARAN}

Perlunya penelitian lanjutan dengan sampel yang lebih besar untuk menilai faktor-faktor lain yang mempengaruhi kepribadian terhadap kejadian relaps pada pasien kanker payudara.

1. Perlunya penelitian lanjutan untuk menilai pengaruh obat kanker payudara terhadap munculnya kejadian relaps pada pasien kanker payudara.

2. Memberikan umpan balik terhadap subyek penelitian mengenai hasil penelitian, serta tetap memberikan psikoedukasi mengenai pentingnya kontrol dan minum obat teratur.

\section{DAFTAR PUSTAKA}

American Cancer Society. Cancer Basic Facts. Cancer Facts \& Figures 2013. Atlanta, Ga.

A. Ahmad, Z.Wang, R. Ali et al. 2012. "Cell cycle regulatory proteins in breast cancer: molecular determinants of drug resistance and targets for anticancer therapies," in Breast Cancer Cells, R. L. Aft, Ed., pp.113-130, InTech.

Brewster AM, Hortobagyi GN, Broglio KR, Kau S-W, Santa Maria CA, Arum B, et al. 2008. Residual Risk of Breast Cancer Reccurent 
5 Years After Adjuvant Therapy. J. Natl Cancer Inst;100:11791183.

Burgess C, Cornelius V, Love S, et al. 2005. Depression and anxiety in women with early breast cancer: five year observational cohort study. 330(7493):702e705.

Brown G, Harris T. 1978. The Bedford College Life-Events and Difficulty. Bedford College, University of London; England

Cobb-Clark D., Schurer S.(2011). 'The stability of big-five personality traits'.IZA Discussion Paper No.5943 . Bonn. Institute for The study of Labor.

Cloninger C.R., Svarick D. M. (2009). 'Personality disorder'.In : Sadock B.J., Sadock V.A., Ruiz P. (EDS) - Kaplan \& Sadock's Comprehensive Textbook of Psychiatry, 9th Edition. Philadelphia. Lippincott Williams \& Wilkins.Pp 2198-2240.

Cardoso F, Costa A, Norton L et al.2012. First International consensus guidelines for advanced breast cancer (ABC 1). Breast 21(3):242-252.

Cohen M. 2002.Coping and emotional distress in primary and recurrent breast cancer patients. J Clin Psychol Med Settings;9:245-251.

Dumitrescu RG, Cotarla I . 2005. Understanding breast cancer risk J Cell Mol Med 9:208-221.

Dalton SO, Boesen EH, Ross L, Schapiro IR, Johansen C. 2002. Mind and cancer. Do psychological factors cause cancer ? Eur $J$ Cancer; 38(10):1313-1323.

Dohrenwend B, Raphael K, Schwartz S, Stueve A, Skodol A. 1984. The structured event probe and narrative rating method for measuring stressful life eventsSEPRATE.

Farquhar C, Marjoribanks J, Lethaby A.(2009) Long term hormone therapy for perimenopausal and postmenopausalwomen. Cochrane Database Syst Rev.

Greer S, Morris T. 1975. Psychological attributes of women who develop breast cancer : a controlled study. J Psychosom Res 19:147-53.

Golden - Kreutz DM, Thornton LM, Wells - DiGregorio, et al. 2005. Traumatic stress, perceived global stress, and life events : Prospectively predicting quality of life in breats cancer patients. Health Psychol;24:288-296 (PubMed 15898865).

Garssen B. 2004. Psychological factors and cancer development : evidence after 30 years of research. Clin Psychol Rev;24(3):315-338.

Heim C, Newport DJ, Graham YP. 2000. Pituitary-Adrenal and Autonomic Response to Stress in Women After Sexual and Physical Abuse in Childhood. JAMA;284:592-597. (PubMed:10918705)

Jennifer Robinson, MD. 2015. Checking for Breast Cancer Reccurence.

Jang KL, Livesley W, Angleitner A, Riemann R, Vernon PA.(2002).Genetic and environmental influences on the covariance of facets defining the domains of the five-factor model of personality. Personality and IndividualDifference;33.83-101.

Kershaw T, Northouse L, Kritpracha C, Schafenacker A, Mood D. 2004. Coping strategies and quality of life in women with advanced breast cancer and their family caregivers. Psychol Health;19:139-155.

Lemeshow .1990.Applied Logistic Regression. New York: Wiley.

Morris T, Greer S, Pettingale KW, Watson M. 1981. Patterns of expressing anger and their psychological correlates in woman with breast cancer. J Psychosom Res 25:111-7.

Mc Crae R.R.,Costa P.T. (2003) Personality in Adulthood Second 
Edition : A Five-Factor

Theory Perspective. New York. The Guilford Press. 2003. Pp 4757

Mc Crae R.R.,Costa P.T. (2008) 'The five-factor theory of personality'. In : John O.P.

Nettle D.(2010). Evolutionary perspectives on the five-factor model of personality.In D.Buss and P.Hawley (Eds).The evolution of personality andindividual differences (pp.5-28).New York, NY:Oxford University Press.

Naoki Nakaya (2003). 'Personality and the Risk of Cancer'. Journal of the National Cancer Institute, vol.95, No 11.Oxford University Press. 2003. Dapat ditemukan di http : //jnci.oxfordjournals.org/ 8 Juli 2015.

Pervin L.A. (2003). 'The science of personality, second edition'. New York. Oxford University Press. 2003. Dapat ditemukan di http://www.oup-usa.org 2 Februari 2009.

Perczek RE, Burke MA, Carver CS, Krongrad A, Terris MK. 2002. Facing a prostate cancer diagnosis : Who is at risk for increased distress ? Cancer ; 94 :2923-2929 .(PubMed 12115380)

Pettingale KW. 1984. Coping and cancer prognosis. J Psychosom Med;28:363-4.

Penke L, Denissen JJA, and Miller GF. 2007). The evolutionary genetics of personality. European Journal of Personality; 21,549-587.

Roesch SC, Adams L, Hines A, et al. 2005.Coping with prostate cancer. A meta - analytic review. J Behav Med ;28:281-293.(PubMed 16015462)

Russell . 2000. Bailey and Love's Short Practice of Surgery. In Chapter onbreast cancer (23rdedn) Arnold, London

R. Siegel, D. Naishadham, and A. Jemal. 2012. "Cancer statistics," CA: A Cancer Journal, vol. 62, pp.1029.

Jurnal Kedokteran

Vol. 05 No. 02 Juni 2020
Robert (Jeff) McCrae and Paul Costa .2008 .Handbook of Personality

Ransom S, Jacobsen PB, Schmidt JE, Andrykowski MA. 2005.

Relationship of problem - focused coping strategies to changes in quality of life following treatment for early stage breast cancer. J Pain Symptom Manage;30:243253. (PubMed: 16183008)

Sprangers MAG, Tempelaar R, Van Den Heuvel WJA, De Haes HCJM. 2002. Explaining quality of life with crisis theory. Psychooncology;1:419-426. (PubMed : 11002237)

Shen Q, Brown P.H. 2003. Novel Agents for the Prevention of Breast Cancer : Targeting Transcription Factors and Signal Transduction Pathways. Journal of Mammary Gland Biology and Neoplasia;8(1) :45-73.

Sephton S, Spiegel D. 2003. Circadian Disruption in Cancer: A neuroendocrine-immune pathway from stress to disease? Brain, Behavior and Immunity; 17(5):321-328.

Selye H.(1976).The stress of life (Revised Edition) New York:McGram-Hill Books Company.

Standish,

Torkelson, Hamill.(2008).Immune defects in breast cancer patients after radiotherapy.JSIO;6:110-121. (PubMed:19087768)

Shiota M.N., Keltner D.,JohnO.P(2006). Positive emotion dispositions differentially associated with Big Five personality and attachment style.TheJournal of Positive Psychology, 1, 61-71.

Schapiro IR, Ross-Petersen L, Sælan H, Garde K, Olsen J, Johansen C (2001) Extroversion and neuroticism and the associated risk of cancer: a Danish cohort study. Am J Epidemiol 153: 757-763. 
Tenibiaje DJ. 2011. Counselling Psychology Ibadan : Esthom Graphic prints.

Widiger T.A. Smith G. T. (2008). 'Personality and psychopathology'.In : John O.P., Robins R.W., Pervin L.A. (EDS) Handbook of Personality Theory and Research Third Edition. New York. The Guilford Press. 2008.

Walshe JM., Swain SM. 2005. Clinical aspect of inflammatory breast cancer. Breast Dis;22: 35-44.

X. Meng, J. Zhong, S. Liu, M. Murray, and A. M. Gonzalez- Angulo. 2012. "A new hypothesis for the cancer mechanism," Cancerand Metastasis Reviews, vol.31, pp. 247-268.

Yuko Minami, Toru Hosokawa, Naoki Nakaya, Yumi Sugawara, Yoshikazu Nishino, Yoichiro Kakugawa, Akira Fukao, Ichiro Tsuji (2015). Personality and breast cancer risk and survival : The Miyagi Cohort Study. 